\title{
Citizen e-Participation as an Important Factor for Sustainable Development
}

\author{
Magdalena Musiał-Karg ${ }^{1}$ and Izabela Kapsa ${ }^{2}$
}

\begin{abstract}
Citizen e-participation - in times of rapid ICT advancement - is an important factor contributing to the development of contemporary democracies. The use of electronic citizen involvement tools provides numerous changes in the relationship between the citizen and public institution, especially by boosting citizen engagement in decision making. Civic participation is a key factor in determining effective and inclusive governance at the local and national levels. As many organizations have recognized, contemporary democracy needs to ensure a responsive, inclusive, participatory and representative decision-making process, emphasizing the importance of those sustainable development factors. Moreover, National Councils for Sustainable Development were once considered critical to achieving integration in decision-making and participation, two dimensions that were at the heart of the sustainable development concept. The article presents citizen e-participation as an important factor for sustainable development. The purpose is to explain theoretical and empirical meaning of citizen e-participation for sustainable development. To achieve this goal, the authors used the following research methods: critical review of the literature and quantitative data analysis (data examined come from author's own research (2018) into use and willingness to use egovernment tools by Poles). Research findings may be an important contribution to the development of civic participation and the implicit value of the process.
\end{abstract}

Keywords: citizen participation, e-democracy, e-government, e-participation, Poland, sustainable development.

\section{Introduction}

To a large extent, today's progress depends on the technological potential, which in turn is associated with rapid development of modern ICT-based tools. Responding to changes that are the consequence of ICT development, as well as application of modern technologies in various areas of social life, has been crucial in both micro and macro dimensions (Jovanović, Dlačić, Okanović, 2018, p. 907). One of key consequences of using electronic tools in political communication and in democratic processes is the growing citizen participation. This results chiefly from the fat that the Internet has become an important medium for individual and collective forms of expressing political views and political mobilization. Therefore, to define those processes we use a number of terms, such as e-democracy, virtual democracy, teledemocracy, digital democracy, and cyber democracy. Moreover, definitions of those terms point to the participation as a precondition, goal or consequence of the phenomenon (Castells, 2001; Della Porta, Mosca, 2005; Stolle et. al, 2005). For example, according to Jan van Dijk and Kenneth Hacker (2000, p.1), digital democracy is "the use of information and communication technology (ICT) and computer-mediated communication (CMC) in all kinds of media (...) for purposes of enhancing political democracy or the participation of citizens in democratic communication". If we consider that democracy evolved from its classical form, through representative democracy, and democracy crisis, to the contemporary 
electronic democracy, the increase in citizen participation seems to be a panacea to the democracy crisis. Since the latter faces a major problem of social anomie, the increase in participation may counteract the issue, and help to return to classical solutions which resort to the direct citizen participation as the core of democracy. In the context of changes and crisis of the democratic system, the article draws attention to one of dimensions of electronic democracy, namely e-participation. A number of scientific and expert publications highlight that we have been dealing with the growth in e-participation of citizens which results from the fact that public institutions focus their activity on active engagement of citizens into democratic processes. Citizen participation is treated as citizens' contribution in the process of implementing and making political decisions, while its electronic model differs from the traditional one due to the use of ICT for communication (Kapsa, 2018, p. 178).

The main research problem described in the article is electronic participation of Poles. The issue has been presented in the form of an analysis of empirical data regarding experience and opinions among Poles on electronic participation, as well as e-voting (which is one of e-participation forms). The analysis focuses on several questions included in the survey with the goal of verifying the following hypotheses: 1 . Citizens expect public services to be provided via electronic channels. 2. The attitude of Poles towards various forms of electronic participation vary depending on their sex, age, education, and domicile. 3. Openness to electronic democracy tools has been growing together with experience in using them. 4. According to the majority of the surveyed, in Poland, voting over the Internet should be introduced as an additional form of participation in elections. The purpose is to explain theoretical and empirical significance of citizen e-participation for sustainable development. To achieve this goal, the authors use the following research methods: critical review of the literature and quantitative data analysis, which have been described in detail in section on Methodology. Considering that civic participation is a key factor in determining effective and inclusive governance at the local and national levels, the contemporary democracy needs to ensure a responsive, inclusive, participatory and representative decision-making process while emphasizing the importance of those factors for sustainable development. The National Council for Sustainable Development, in its 2030 Agenda for Sustainable Development, (https://sustainabledevelopment.un.org), considers two dimensions that were at the heart of the sustainable development concept. They are critical to achieving integration and participation in decision-making.

\section{Citizen e-Participation for Sustainable Development}

The foundation of the sustainable development concept comprises a multidimensional and comprehensive development which is based on permanence and periodical improvement in the quality of life. (Sobol, Krakowiak-Drzewiecka, Dobosiewicz, 2017). One of important elements of the process (sustainable development) in a state, region or city is the focus on socialization. Active engagement of citizens guarantees better understanding of societal needs, and consequently enhanced efficacy of activities and policies. The contemporary discussion on the participative democracy considers it to be one of key elements (Barber, 1984). In particular, in recent years, we can see that "ideas and reality of sustainable development and democracy 
overlap and are interdependent. Common to both sustainable development and democracy is participation" (Westall, 2015, p. 1).

In the era of ICT development - notably the Internet - active engagement of citizens and their increased participation, e.g. in decision making, is possible due to eparticipation (Musiał-Karg, 2014, 2017). "ICT serves as a toolbox for reaching out and engaging the public on governmental policies thereby drawing government closer to citizens in policy and decision making" (Kyere \& Kumah, 2017). A number of researchers indicate that the omnipresent digitalization is correlated with sustainable development., and one of areas where the process is particularly vivid is the participatory space. Researchers consider that the use of ICT (apart from its potential in reducing digital divide) should primarily motivate and engage citizens to ensure broader participation in decision-making and to improve the transparency and accountability of the governance at national, regional or local levels (Islam, 2008). Civic engagement through ICT (e-participation) seems to be necessary. One of reasons is the fact that participation in civic affairs, especially in democratic elections as highlighted by the OECD, exhibits a declining trend (OECD, 2001). It is worth mentioning that researcher studying the topic included Milic Jovanović, Jasmin Dlačić and Milan Okanović (2018), Gustav Lidén (2012), Peter Seele and Irina Lock, (2017), Liezel Lueas (2014) or Francis Kyere \& Naana Yaa Gyamea Kumah (2017). While examining case studies of various countries, the above mentioned authors noticed that the concept of sustainable development (including social one) was related to the ICT, as expressed by the use of information and communication technologies to support the development (ICT4D) (Ochara, Mawela). Undoubtedly, in the time of rapid ICT development, the socialization of the sustainable development process necessitates the use of e-participation tools. Moreover, e-participation may translate into an enhanced engagement of societies in consultation and decision making both at state and local levels.

\section{Methodology}

The 2018 survey covered a sample of 1717 Poles. The sampling was done based on quota and demographic features of the population. In each province, the size of the sample was proportional to its total population. The sampling also took into consideration sex and age. Once the criteria were met, the snowball sampling was used to select people to be surveyed. In the case of the electronic questionnaire, all web users could fill it in. Respondents had a choice between paper and electronic versions of the questionnaire. The questionnaire consisted of respondent's particulars and questions referring to the participation in elections and political preferences, use of the Internet, as well as a number of statements on electronic voting and electronic administration. The article presents findings based on answers given to the following statements:

1. I use electronic administration services (e.g. I send documents to institutions over Internet, I send email to authorities, I send my tax returns via Internet etc.).

2. I would like to have more opportunities to deal with official matters over the Internet in Poland.

3. Poland should introduce Internet voting as an additional form of participation in elections. 
4. If possible, I would use Internet voting during elections.

The selection of statements to be presented in the article is based on the conviction of the authors that they express the attitude (or experience) of the respondents to various forms of citizen participation, such as e-voting and e-government (e-gov). Answers are expressed using the Likert scale, and respondents could choose one out of five possible options: definitely yes, rather yes, yes, hard to say, rather no, definitely no. While processing results, each option was expressed in numbers as follows: definitely yes -5 points, rather yes -4 points, hard to say -3 points, rather no -2 points, definitely no -1 point.

In the attempt to find the answer to research questions, analyses of basic descriptive statistics were performed accompanied by Kolmogorov-Smirnov tests, Mann-Whitney $U$ tests, Kruskal-Wallis tests, $\chi 2$ tests and Fisher's exact tests. The significance level was determined at the classical cutoff value $\alpha=0.05$; However, probability results at $0.05<\mathrm{p}$ $<0.1$ were interpreted as significant at the statistical tendency level.

\section{Results of Empirical Research}

The presentation starts with primary descriptive statistics for quantitative variables together with the Kolmogorov-Smirnov (K-S) test which verified the normal distribution of variables. According to table 1, all distributions examined differed significantly from the Gauss distribution, as supported by the K-S test. However, the skewness of those distributions remained within the range of -2 to +2 . Therefore, we may assume that distributions were not significantly asymmetrical around their median.

The table below contains figures (expressed as percentage of answers) which enable to verify hypothesis no 1: Citizens expect public services to be provided via electronic channels; as well as hypothesis no 4: According to the majority of the surveyed, in Poland, voting over the Internet should be introduced as an additional form of participation in elections. Assuming that statement two (I would like to have more opportunities to deal with official matters over the Internet in Poland) expresses the expectation of the public towards e-public services, we may say that the hypothesis was successfully verified. Nearly $80 \%$ of respondents answered "yes" to the statement, and the median (M) for their answers was 4.28. A similar situation is with statement three (Poland should introduce Internet voting as an additional form of participation in elections) which enables a positive verification of hypothesis no 4 . Nearly $70 \%$ of respondents answered "yes" to the statement, and the median for their answers was 3.92.

Tab. 1. Answers to statements regarding e-gov and e-voting.

\begin{tabular}{|l|c|c|c|c|c|c|c|c|}
\hline Statement & $\mathbf{5}$ & $\mathbf{4}$ & $\mathbf{3}$ & $\mathbf{2}$ & $\mathbf{1}$ & $\mathbf{M}$ & $\mathbf{K}-\mathbf{S}$ & $\mathbf{p}$ \\
\hline $\begin{array}{l}\text { I use electronic administration services (e.g. I } \\
\text { send documents to institutions over Internet, } \\
\text { I send email to authorities, I send my tax } \\
\text { returns via Internet etc.) }\end{array}$ & $31.45 \%$ & $27.8 \%$ & $5.4 \%$ & $16.43 \%$ & $14.91 \%$ & 3.46 & 0.26 & $<0.001$ \\
\hline $\begin{array}{l}\text { I would like to have more opportunities to } \\
\text { deal with official matters over the Internet in } \\
\text { Poland. }\end{array}$ & $55.37 \%$ & $23.24 \%$ & $9.06 \%$ & $5.68 \%$ & $2.64 \%$ & 4.28 & 0.33 & $<0.001$ \\
\hline $\begin{array}{l}\text { Poland should introduce Internet voting as an } \\
\text { additional form of participation in elections. }\end{array}$ & $40.91 \%$ & $28.64 \%$ & $14.8 \%$ & $7.2 \%$ & $4.39 \%$ & 3.98 & 0.24 & $<0.001$ \\
\hline $\begin{array}{l}\text { If possible, I would use Internet voting during } \\
\text { elections. }\end{array}$ & $43.5 \%$ & $25.49 \%$ & $9.68 \%$ & $9.74 \%$ & $7.26 \%$ & 3.92 & 0.26 & $<0.001$ \\
\hline
\end{tabular}


To verify hypothesis no 3: Openness to electronic democracy tools has been growing together with experience in using them, we used a test for two results, namely answers to the first (information about use of e-gov) and second (declaration of willingness to use egov) statements. According to the table above, more than a half of the surveyed use electronic administration services (59.25\% of respondents), and nearly $80 \%$ of them would like to have more e-public services. Test results show that positive correlation of answers to the two questions (considerably high level of 0.6013), which means that the more points are given for answers to statement one, the higher the number of points assigned to statement two. In other words, if someone uses e-gov services, the person would like to have more such services offered.

To verify hypothesis two: The attitude of Poles towards various forms of electronic participation vary depending on their sex, age, education, and domicile, the analysis should be broadened. Results of such an analysis are presented in tables below. While examining results for different sex, it turns out that answers given by women and men do not show statistically significant differences. Medians for both groups are of similar value. Only in the case of statement 4 (If possible, I would use Internet voting during elections), a difference was recorded at the level of a statistical tendency. The power of all effects noted was rather low. As regards other statements, no differences were recorded, not even at the level of a statistical tendency. Results are shown in a graphic form in table 2. In the case of quantitative variables, a series of non-parametrical MannWhitney $\mathrm{U}$ tests were performed due to significant differences in the composition of groups compared, whereas in the case of nominal variables, a series of $\chi^{2}$ tests were performed. Abbreviations used in the table: M - median; SD - standard deviation; U Mann-Whitney $U$ test result; $\mathrm{p}$ - statistical significance; $\mathrm{r}$ - effect size.

Tab. 2. Sex of the surveyed and answers to selected statements.

\begin{tabular}{|l|c|c|c|c|c|c|c|c|}
\hline & \multicolumn{2}{|c|}{ Female } & \multicolumn{2}{|c|}{ Male } & \multicolumn{4}{|c|}{} \\
\hline & $\mathrm{M}$ & $\mathrm{SD}$ & $\mathrm{M}$ & $\mathrm{SD}$ & $\mathrm{U}$ & $\mathrm{Z}$ & $\mathrm{p}$ & $\mathrm{r}$ \\
\hline I use electronic administration services. & 3.42 & 1.51 & 3.52 & 1.44 & 350402.5 & -0.91 & 0.362 & 0.02 \\
\hline $\begin{array}{l}\text { I would like to have more opportunities to deal } \\
\text { with official matters over the Internet in Poland }\end{array}$ & 4.28 & 1.04 & 4.29 & 1.03 & 358509.0 & -0.09 & 0.931 & 0.00 \\
\hline $\begin{array}{l}\text { Poland should introduce Internet voting as an } \\
\text { additional form of participation in elections. }\end{array}$ & 4.00 & 1.12 & 3.96 & 1.15 & 351553.5 & -0.75 & 0.452 & 0.02 \\
\hline $\begin{array}{l}\text { If possible, I would use Internet voting during } \\
\text { elections. }\end{array}$ & 3.98 & 1.25 & 3.86 & 1.32 & 338355.0 & -1.86 & 0.063 & 0.05 \\
\hline
\end{tabular}

Although sex had no influence on differences in answers given by respondents, their answers varied depending on their age. Major differences were recorded in the group $65+$ as regards answers to the first statement: "I use electronic administration services" (about $40 \%$ of respondents in that group stated "definitely yes" or "rather yes", and about 50\% "definitely no" or "rather no", median was 2.69). The group was statistically significantly different than all other groups. The highest results were noted in groups 25 34 (median 3.81) and 35-44 (median 3.91), in which ca. 75\% of the surveyed answered "definitely yes" or "rather yes" to the statement. Although the groups did not differ also regarding the level of statistical tendency, they were different from three other age groups. As regards statistical significance, other differences between groups are 
negligible. Similar situation was regarding answers to the second statement: "I would like to have more opportunities to deal with official matters over the Internet in Poland". The lowest result was recorded in the oldest age group (slightly less than $60 \%$ answers were "definitely yes" and "rather yes", median 3.65). That group showed statistically significant difference from other groups. Slightly higher results were recorded for groups of 45-54 and 55-64 (median 4.36 and 4.09). Although the groups did not differ, not even at the level of a statistical tendency, they were different than three other age groups, in which about $90 \%$ of positive answers were given to that statement (median 4.51 and 4.53). As regards statistical significance, other differences between groups are negligible. We have observed similar tendencies as regards answers to the question on e-voting. The lowest results were recorded in the group of $65+$. In the case of the first statement (Poland should introduce Internet voting as an additional form of participation in elections), the group showed statistically significant differences from other age groups except 55-64 (about 58\% of 65+ respondents gave positive answer to that question, median 3.62). The group differed only from the group of the highest level of positive answers, namely the group of $35-44$ (nearly $80 \%$ positive answers, median 4.23). As regards statistical significance, other differences between groups were negligible. As regards the other statement (If possible, I would use Internet voting during elections), members of the oldest age group were the least convinced as to that statement (about $50 \%$ of positive answers, median 3.26) and showed statistically significant difference from other groups. As regards statistical significance, other differences between groups are negligible. The only statistically significant differences were noted between the group of 55-63 and 35-44. The table below (tab. 3) shows results of a series of Kruskal-Wallis tests. Statistically significant results are recorded for almost all items. Non-parametric multivariate analyses were performed due to quantitative differences between groups, followed by $\chi^{2}$ tests and Fisher's exact tests. Letters are used to mark statistically significant differences at the level of $\mathrm{p}<0.05$ (post-hoc Dunn-Sidak tests).

Tab. 3. Age of respondents and answers to statements.

\begin{tabular}{|c|c|c|c|c|}
\hline & Age & $\mathrm{M}$ & SD & \\
\hline \multirow{6}{*}{ I use electronic administration services. } & $18-24$ & $3.40 \mathrm{~b}$ & 1.41 & \\
\hline & $25-34$ & $3.81 \mathrm{c}$ & 1.32 & \\
\hline & $35-44$ & $3.91 \mathrm{c}$ & 1.25 & $H(5)=128.44$ \\
\hline & $45-54$ & $3.57 \mathrm{~b}$ & 1.47 & $p<0.001$ \\
\hline & $55-64$ & $3.28 \mathrm{~b}$ & 1.50 & \\
\hline & $65+$ & $2.69 \mathrm{a}$ & 1.59 & \\
\hline \multirow{6}{*}{$\begin{array}{l}\text { I would like to have more opportunities to deal with } \\
\text { official matters over the Internet in Poland. }\end{array}$} & $18-24$ & $4.51 \mathrm{c}$ & 0.76 & \\
\hline & $25-34$ & $4.51 \mathrm{c}$ & 0.83 & \\
\hline & $35-44$ & $4.53 \mathrm{c}$ & 0.81 & $H(5)=133.84$ \\
\hline & $45-54$ & $4.36 \mathrm{~b}$ & 0.93 & $p<0.001$ \\
\hline & $55-64$ & $4.09 \mathrm{~b}$ & 1.15 & \\
\hline & $65+$ & $3.65 a$ & 1.34 & \\
\hline \multirow{6}{*}{$\begin{array}{l}\text { Poland should introduce Internet voting as an additional } \\
\text { form of participation in elections. }\end{array}$} & $18-24$ & $4.04 \mathrm{~b}$ & 1.06 & \\
\hline & $25-34$ & $4.08 \mathrm{~b}$ & 1.11 & \\
\hline & $35-44$ & $4.23 \mathrm{c}$ & 1.02 & $H(5)=47.93$ \\
\hline & $45-54$ & $4.03 \mathrm{~b}$ & 1.04 & $p<0.001$ \\
\hline & 55-64 & $3.88 \mathrm{ab}$ & 1.22 & \\
\hline & $65+$ & $3.62 \mathrm{a}$ & 1.27 & \\
\hline
\end{tabular}




\begin{tabular}{|l|c|c|c|c|}
\hline & $18-24$ & $4.13 \mathrm{~b}$ & 1.13 & \\
\cline { 2 - 5 } & $25-34$ & $4.05 \mathrm{~b}$ & 1.18 & \\
\cline { 2 - 5 } & $35-44$ & $4.22 \mathrm{~b}$ & 1.05 & $H(5)=82.53$ \\
\cline { 2 - 5 } & $45-54$ & $4.02 \mathrm{~b}$ & 1.16 & $p<0.001$ \\
\cline { 2 - 5 } & $55-64$ & $3.85 \mathrm{~b}$ & 1.35 & \\
\cline { 2 - 5 } & $65+$ & $3.26 \mathrm{a}$ & 1.54 & \\
\hline
\end{tabular}

According to the analyses of the median in particular age groups we can see that results are inversely proportional to the age of the surveyed from the oldest to the average age groups. The lowest results regarding all statements are recorded in the oldest group, whereas the highest in 35-44. A slight drop from the lowest median can be found in groups of 25-34 and 18-24.

Answers also varied depending on the education level. It should be mentioned that the group of uneducated people consisted of two people only. Although, these people have not be eliminated from the analysis and their answers are presented, it is does not make much sense to examine differences between this little populous group and other much larger groups. Non-parametric variance analyses and Fisher's exact tests were performed to compare groups due to major differences in the number of respondents. The analysis focused on answers to statements (table 4) using Kruskal-Wallis tests, and the analysis showed statistically significant results in nearly all items.

As regards the first statement, convergence was the highest in the group of people having higher education to produce the highest result (median 3.77). The group showed statistically significant differences comparing to other groups except the group of respondents with no education. Slightly lower results are recorded in the group of people with middle and post-secondary education. The group showed statistically significant differences comparing with groups of primary/junior secondary education (the lowest results, median 2.03) and vocational education (median 2.61). As regards statistical significance, other differences between groups are negligible. As regards statement two, four statistically significant differences were recorded. Groups of higher results - with middle/post-secondary and higher education showed statistically significant differences comparing with groups of primary/junior secondary and vocational education. As regards statistical significance, other differences between groups are negligible. Concerning statement three, five statistically significant differences were recorded. People who agreed with the statement included respondents with higher education. The groups showed statistically significant differences from three other groups, namely people with primary/junior secondary, vocational and middle/post-secondary education. The middle education group also showed high results. The group showed statistically significant differences comparing with people of primary/junior secondary and vocational education. As regards statistical significance, other differences between groups are negligible. As regards the final statement, four statistically significant differences were recorded. Groups of higher scores (middle/post-secondary and higher education) showed statistically significant differences comparing with groups of primary/junior secondary and vocational education. As regards statistical significance, other differences between groups were negligible. 
Tab. 4. Education of respondents and responses to statements.

\begin{tabular}{|c|c|c|c|c|}
\hline & Education & $\mathrm{M}$ & SD & \\
\hline \multirow{5}{*}{ I use electronic administration services. } & none & $3.50 \mathrm{abc}$ & 0.71 & \\
\hline & primary/junior secondary & $2.03 \mathrm{a}$ & 1.19 & $H(4)=118.38$ \\
\hline & vocational & $2.61 \mathrm{a}$ & 1.59 & $p<0.001$ \\
\hline & secondary/post-secondary & $3.33 \mathrm{~b}$ & 1.44 & \\
\hline & higher & $3.77 \mathrm{c}$ & 1.39 & \\
\hline \multirow{5}{*}{$\begin{array}{l}\text { I would like to have more opportunities to deal } \\
\text { with official matters over the Internet in Poland. }\end{array}$} & none & $4.00 \mathrm{ab}$ & 1.41 & \\
\hline & primary/ junior secondary & $2.67 \mathrm{a}$ & 1.27 & $H(4)=154.86$ \\
\hline & vocational & $3.44 \mathrm{a}$ & 1.30 & $p<0.001$ \\
\hline & secondary/post-secondary & $4.33 \mathrm{~b}$ & 0.95 & \\
\hline & higher & $4.45 b$ & 0.90 & \\
\hline \multirow{5}{*}{$\begin{array}{l}\text { Poland should introduce Internet voting as an } \\
\text { additional form of participation in elections. }\end{array}$} & none & $3.00 \mathrm{ab}$ & 0.00 & \\
\hline & primary/ junior secondary & $3.00 \mathrm{a}$ & 1.15 & $H(4)=63.16$ \\
\hline & vocational & $3.56 a$ & 1.17 & $p<0.001$ \\
\hline & secondary/post-secondary & $3.97 \mathrm{~b}$ & 1.10 & \\
\hline & higher & $4.11 \mathrm{c}$ & 1.12 & \\
\hline \multirow{5}{*}{$\begin{array}{l}\text { If possible, I would use Internet voting during } \\
\text { elections. }\end{array}$} & none & $4.00 \mathrm{ab}$ & 1.41 & \\
\hline & primary/ junior secondary & $2.48 \mathrm{a}$ & 1.38 & $H(4)=81.61$ \\
\hline & vocational & $3.24 \mathrm{a}$ & 1.40 & $p<0.001$ \\
\hline & secondary/post-secondary & $3.98 \mathrm{~b}$ & 1.23 & \\
\hline & higher & $4.05 \mathrm{~b}$ & 1.23 & \\
\hline
\end{tabular}

The analysis of the median in particular groups by age (excluding uneducated people) shows that results are proportional to the level of education. This means that the higher the education, the higher number of answers to a given statement.

The final demographic factor taken into consideration while examining answers to statements was domicile. I performed a series of Kruskal-Wallis tests which showed statistically significant results in nearly all items (table 5). As regards the first statement, the highest results were recorded in the group of people living in rural areas. This group differed from people living in cities with population of 20-100 thou., 100-200 thou., 200500 thou. and cities which population exceeded 500 thou. Other differences were not statistically significant. As regards the second statement, two statistically differences were recorded. The highest level of convergence with a statement was recorded in the group of people living in large cities (exceeding 500 thou.). This groups sowed statistically significant differences comparing with people living in cities up to 20 thou. Additionally, a difference at the statistical tendency level was recorded between inhabitants of rural areas, who had the lowest results in this variable, and inhabitants of cities with population of 20-100 thou. Other differences were not statistically significant, even at the level of the statistical tendency. As regards statement three, the highest results were recorded in the group of inhabitants of cities with population exceeding 500 thou. This group showed a statistically significant difference comparing with other groups, except inhabitants of cities with population of 20-100 thou. Additionally, a difference was recorded between inhabitants of rural areas, who least agreed with the statement, and inhabitants of cities with population of 100-200 thou. Other differences were not statistically significant. As regards statement four, again the highest results were recorded in the group of inhabitants of large cities with population in excess of 500 thou. The group showed a statistical difference comparing with inhabitants of rural areas and cities 
with population up to 100 thou. Moreover, inhabitants of rural areas, who had the lowest level of convergence with statement four, showed statistical differences comparing with the group of inhabitants of cities with population of 20-100 thou. and, at the level of a statistical tendency, comparing with inhabitants of cities with population of 200-500 thou. Other differences were not statistically significant.

Tab. 5. Domicile of people surveyed and their assessment of selected statements.

\begin{tabular}{|c|c|c|c|c|}
\hline & Domicile & $\mathrm{M}$ & SD & \\
\hline \multirow{6}{*}{ I use electronic administration services. } & Rural & $3.20 \mathrm{a}$ & 1.53 & \\
\hline & City up to 20 thou. & $3.47 \mathrm{ab}$ & 1.43 & \\
\hline & City of 20-100 thou. & $3.62 \mathrm{~b}$ & 1.43 & $\mathrm{H}(5)=26.68$ \\
\hline & City of $100-200$ thou. & $3.59 \mathrm{~b}$ & 1.44 & $\mathrm{p}<0.001$ \\
\hline & City of 200-500 thou. & $3.54 \mathrm{~b}$ & 1.50 & \\
\hline & Above 500 thou. & $3.68 \mathrm{~b}$ & 1.40 & \\
\hline \multirow{6}{*}{$\begin{array}{l}\text { I would like to have more opportunities to deal } \\
\text { with official matters over the Internet in Poland. }\end{array}$} & Rural & $4.15 \mathrm{a}$ & 1,12 & \\
\hline & \begin{tabular}{|l} 
City up to 20 thou. \\
\end{tabular} & $4.19 \mathrm{a}$ & 1,07 & \\
\hline & City of $20-100$ thou. & $4.35 \mathrm{ab}$ & 1,03 & $\mathrm{H}(5)=29.64$ \\
\hline & City of $100-200$ thou. & $4.31 \mathrm{ab}$ & 1,01 & $\mathrm{p}<0.001$ \\
\hline & City of 200-500 thou. & $4.30 \mathrm{ab}$ & 1,04 & \\
\hline & Above 500 thou. & $4.55 \mathrm{~b}$ & 0,77 & \\
\hline \multirow{6}{*}{$\begin{array}{l}\text { Poland should introduce Internet voting as an } \\
\text { additional form of participation in elections. }\end{array}$} & Rural & $3.85 \mathrm{a}$ & 1.19 & \\
\hline & City up to 20 thou. & $3.92 \mathrm{ab}$ & 1.11 & \\
\hline & City of $20-100$ thou. & 4.10abc & 1.06 & $\mathrm{H}(5)=23.61$ \\
\hline & City of $100-200$ thou. & $4.18 \mathrm{~b}$ & 0.98 & $\mathrm{p}<0.001$ \\
\hline & City of $200-500$ thou. & 3.96abc & 1.18 & \\
\hline & Above 500 thou. & $4.15 c$ & 1.09 & \\
\hline \multirow{6}{*}{$\begin{array}{l}\text { If possible, I would use Internet voting during } \\
\text { elections. }\end{array}$} & Rural & $3.77 \mathrm{aT}$ & 1.31 & \\
\hline & City up to 20 thou. & $3.80 \mathrm{ab}$ & 1.33 & \\
\hline & City of 20-100 thou. & $4.09 \mathrm{bc}$ & 1.20 & $\mathrm{H}(5)=26.86$ \\
\hline & City of $100-200$ thou. & $3.98 \mathrm{abc}$ & 1.20 & $p<0.001$ \\
\hline & City of $200-500$ thou. & 3.99abcT & 1.31 & \\
\hline & Above 500 thou. & $4.10 \mathrm{c}$ & 1.24 & \\
\hline
\end{tabular}

The analysis of the median of answers given by representatives of particular groups depending on their domicile show that there is no simple linear relationship between the domicile and results of the survey. However, two linear functions can be determined: from inhabitants of rural areas to cities with population of 20-100 thou. and from inhabitants of cities with population of 100-200 thou. to inhabitants of cities with population of 500 thou.

\section{Conclusions and Implications}

The empirical study enabled to verify hypothesis no 1: Citizens expect public services to be provided via electronic channels (median 4.28), and hypothesis no 4: According to the majority of the surveyed, in Poland, voting over the Internet should be introduced as an additional form of participation in elections (median 3.92). Hypothesis no 3 also underwent a positive verification, i.e. if someone uses e-gov services, the person would like to see more such services to be available. A number of analyses were 
performed to verify hypothesis no 2 . The analyses lead to the following conclusions:

a) Sex does not determine differences in responses to statements related to egovernment and e-voting. Responses given by women and men do not show statistically significant differences. Medians for both groups have similar values.

b) Age does have impact on answers given by respondents. Older people are less convinced to use electronic tools, whereas younger people show larger diversity regarding their opinions about possible use of such tools.

c) Education level also has its influence on responses given to selected statements. The education level is proportional to results of the survey, in other words openness to electronic tools and experience in the area concerned increase with the education level.

d) The above is also true regarding the domicile. However, in this particular area, two locations stand out by results noted. The lowest results are recorded among people living in rural areas, the highest among inhabitants of large cities (in excess of 500 thou.) and medium-sized cities with population of 20-100 thou.

Although the study provides a diagnosis of the status quo, it does not explain underlying reasons. It is a challenge and encouragement to continue research into the subject. We ham assume, however, that reasons for differences correspond to factors determining the development of e-administration. In the context of results presented, it is worth to pay attention to the development of information society, socio-economic development, accessibility to IT infrastructure for citizens and companies, as well as the basis, knowledge and skills among citizens and the size of an administrative unit (Perdał, 2014, p. 85). These factors comprise the foundation of a comprehensive development that contributes to enhanced life quality, which lay at the foundation of the sustainable development concept. Today, the socialization of the process is based on active engagement of citizens, which is confirmed by the participative democracy concept. In the ear of growing use of the Internet, active engagement of citizens and increasing their participation in decision making are possible due to e-participation tools. Understanding of the operation of those tools as well as the way they are perceived by the society is crucial for further development. A good example of the above are the findings of the survey presented in the article.

\section{Acknowledgement}

Paper prepared under the project: E-voting as an alternative voting procedure in state elections. Experience of selected countries and the perspectives of e-voting implementation in Poland: UMO-2014/15/B/HS5/01358 (NCN, OPUS program).

\section{References}

Barber, B.R. (1984). Strong Democracy: Participatory Politics for a New Age, University of California Press.

Castells, M. (2001). The Internet Galaxy: Reflections on the Internet, Business, and Society. Oxford: Oxford University Press.

Della Porta, D., Mosca, L. (2005). Global-net for Global Movements? A Network of Networks for a Movement of Movements. Journal of Public Policy, 25(1), pp. 165-190.

Hacker, K.L., van Dijk, J. (2000). Digital Democracy: Issues of Theory and Practice. London: SAGE Publications. 
Islam, M.S. (2008). Towards a sustainable e-Participation implementation model, European Journal of ePractice.

Jovanović M., Dlačić J., Okanović M. (2018). Digitalization and Society's Sustainable Development Measures and Implications. Zbornik Radova Ekonomskog Fakulteta u Rijeci / Proceedings of Rijeka School of Economics 36(2), pp. 905-928.

Kapsa, I. (2018). Civic E-Participation in Central and Eastern Europe: A Comparative Analysis. International Journal of Humanities and Social Sciences, 12(1), pp. 177-82.

Kyere, F., Kumah, N. Y. G. (2017). The Imperative of E-Participation in Sustainable Community Development in Ghana. Journal of Public Administration and Governance, vol. 7, no. 4, pp. 211 223.

Lidén, G (2012). Is e-democracy more than democratic? - An examination of the implementation of socially sustainable values in e-democratic processes. Electronic Journal of e-Government, vol. 10 no. 1, pp.84 - 94 .

Lues, L. (2014). Citizen participation as a contributor to sustainable democracy in South Africa. International Review of Administrative Sciences, vol. 80 no. 4, pp. 789-807.

Musiał-Karg, M. (2017), Electronic Voting as an Additional Method of Participating in Elections. Opinions of Poles. in: Krimmer R. et al. (eds) Electronic Voting. E-Vote-ID 2016. Lecture Notes in Computer Science, vol. 10141. Springer, Cham, pp. 218-232.

Musiał-Karg, M. (2014), The use of e-voting as a new tool of e-participation in modern democracies, Przegląd Politologiczny, no. 4, pp. 99-110.

Ochara, N.M., Mawela, T., Enabling Social Sustainability of E-Participation through Mobile Technology, https://pdfs.semanticscholar.org/e37e/f680e4a70a39dc10b1a5b01a5c284dc975be.pdf.

Organization for Economic Co-operation and Development -OECD (2001). Citizens as partners: OECD handbook on information. Consultation and public participation in policy-making, OECD, Paris.

Perdał, R. (2014). Czynniki rozwoju elektronicznej administracji w samorządzie lokalnym w Polsce. Poznań: Bogucki Wydawnictwo Naukowe.

Seele, P., Lock, I. (2017), The game-changing potential of digitalization for sustainability: Possibilities, Perils, and Pathways. Sustainability Science, 12(2), pp.183-185.

Stolle, D. et. al. (2005). Politics in the Supermarket: Political Consumerism as a Form of Political Participation. International Political Science Review, 26(3), pp. 245-269.

Westall A. (2015). The Relationship between Democracy and Sustainable Development, Foundation for Democracy and Sustainable Development. 